\title{
o4. Türkçe öğretimi için kaynak kitap yazıyorum çünkü...: Bir olgu bilim araştırması
}

\author{
Banu ÖZDEMİR' \\ Yasin AYDOĞAN2
}

APA: Özdemir, B.; Aydoğan, Y. (2021). Türkçe öğretimi için kaynak kitap yazıyorum çünkü...: Bir olgu bilim araştırması. RumeliDE Dil ve Edebiyat Araştırmaları Dergisi, (24), 34-54. DOI: 10.29000/rumelide.990075.

\section{$\ddot{O} \mathbf{z}$}

Ders kitapları eğitim ve öğretimin vazgeçilmez unsurları arasında yer almaktadır. Ders kitaplarının içeriği dersin özelliği, eğitim programının hedeflerine uygunluğu, öğretme-öğrenme süreci boyunca kullanılacak ölçme ve değerlendirme yöntemlerine uygunluğu bakımından kabul görür bir şekilde hazırlanmış olmalıdır. Tüm bu özellikler gözetilerek hazırlanan ders kitapları, hem öğretmenlerin öğretme süreçlerinde vazgeçilmez bir araç hem de öğrenme sürecinde öğrencilerin temel başvuru kaynağıdır. Eğitim ve öğretim faaliyetlerinin etkililiğini artırmak isteyen öğretmenler, ders kitaplarının yanı sıra yardımcı kaynakları da kullanmaya başlamışlardır. Eğitim programının hedeflediği kazanımları desteklemek ve öğrencileri girecekleri sınavlara hazırlamak için kaynak kitaplar zorunlu olmadığı halde yoğun bir şekilde kullanılmaktadır. Bu ilgi neticesinde son zamanlarda özellikle Türkçe öğretmenleri tarafından kaynak kitap yazımı gittikçe artmaktadır. Bu çalışmanın amacı kaynak kitap yazan Türkçe öğretmenlerinin bu deneyimlerine ilişkin görüşlerini anlamaktır. Çalışma nitel araştırma yöntemlerinden olgu bilim desenine uygun olarak tasarlanmıştır. Katılımcılar amaçlı örnekleme yoluyla belirlenmiştir. Araştırmanın katılımcılarını MEB' e bağlı kurumlarda Türkçe öğretmeni olarak görev yapan ve ulusal düzeyde satışı yapılan kaynak kitap yazarları oluşturmaktadır. Veriler yarı yapılandırılmış görüşme formu aracılığıyla çevrimiçi araçlar yoluyla görüşülerek toplanmıştır. Veriler içerik analizi tekniğiyle çözümlenmiştir. Araştırmada öğretmenlerin neden kaynak kitap yazmaya ihtiyaç duyduklarına, Türkçe öğretiminde kaynak kitapların rolüne ve süreçte karşılaştıkları sorunlara yönelik görüşleri ortaya koyulmaya çalışılmıştır. Çalışmanın sonucunda ortaya çıkan görüşlerin öğretmenlere ve kurumsal politikalara katkı sağlayacağı düşünülmektedir.

Anahtar kelimeler: Türkçe öğretimi, kaynak kitap, kitap yazarı

\section{I am writing a sourcebook for teaching Turkish ...: A phenomenological study}

\begin{abstract}
Textbooks are among the indispensable elements of education and instruction. The content of textbooks should be prepared in compliance with the characteristics of the course, the objectives of the curriculum, and the measurement and evaluation methods to be used throughout the teachinglearning process. Prepared by considering all these features, textbooks are both an indispensable tool in the teaching process for teachers and the main reference source for students in the learning
\end{abstract}

Dr. Öğr. Üyesi., Kütahya Dumlupınar Üniversitesi, Eğitim Fakültesi, Türkçe ve Sosyal Bilimler Eğitimi Bölümü, Türkçe Eğitimi ABD (Kütahya, Türkiye), banu.ozdemir@dpu.edu.tr ORCID ID: oooo-ooo2-4298-8569 [Araştırma makalesi, Makale kayit tarihi: 20.05.2021-kabul tarihi: 20.09.2021; DOI: 10.29000/rumelide.990075]

MEB, Türkçe Öğretmeni, Fatih Ortaokulu (Kütahya, Türkiye), yasinaydogan81@gmail.com,, ORCID ID: oooo-ooo29495-7959

Adres
RumeliDE Dil ve Edebiyat Araştırmaları Dergisi Osmanağa Mahallesi, Mürver Çiçeği Sokak, No:14/8 Kadıköy - ISTANBUL / TÜRKIYE 34714 e-posta: editor@rumelide.com tel: +90 $5057958124,+902167730616$
Address

RumeliDE Journal of Language and Literature Studies Osmanağa Mahallesi, Mürver Çiçeği Sokak, No:14/8

Kadıköy - ISTANBUL / TURKEY 34714

e-mail: editor@rumelide.com,

phone: +90 5057958124 , +90 2167730616 
process. In Turkish teaching, besides textbooks, sourcebooks prepared by teachers to be used in teaching Turkish are also used. Teachers who wanted to increase the effectiveness of educational and instructional activities started to use supplementary sources as well as textbooks. Although not mandatory, sourcebooks are used extensively to support the accomplishment of the objectives set in a curriculum and to prepare students for the exams they will take. As a result of this interest, writing of sourcebooks has been increasing, particularly by Turkish teachers. The purpose of the current study is to understand the views of Turkish teachers who have written sourcebooks about this experience of writing. The study was designed in accordance with the phenomenological design, one of the qualitative research methods. The participants of the study were determined by using the purposive sampling method. The participants of the study are sourcebook writers who work as Turkish teachers in the institutions affiliated to the Ministry of National Education and whose sourcebooks are sold at the national level. The data were collected through interviews conducted on an online environment by using a semi-structured interview form. The collected data were analyzed with the content analysis technique. As a result of the analysis, it was attempted to reveal the participating teachers' opinions about the need for sourcebooks, the role of sourcebooks in teaching Turkish and the problems they experienced during the sourcebook writing process. The results obtained in the current study are believed to make important contributions to teachers and institutional policies.

Keywords: Teaching Turkish, sourcebook, book writer

\section{Giriş}

Öğrencilerin belirlenen kazanımlara ulaşması ve kazanımlara uygun davranışları sergilemesinde ders kitapları oldukça önemli yer tutmaktadır. Ayrıca ders kitapları öğrencilerin bağımsız bir şekilde öğrenmelerinde kullandıkları etkili bir araçtır. "Ders kitabı, bir eğitim programında yer alan hedef, içerik, öğretme-öğrenme süreci ile ölçme değerlendirme boyutlarına uygun hazırlanmış ve öğrenme amaçlı kullanılan basılı bir öğretim materyalidir.” Demirel ve Kıroğlu (2019:2). Ünsal ve Güneş’e (2004) göre ders kitapları, öğretim programlarında yer alan konulara ait bilgileri planlı ve düzenli bir biçimde inceleyip açıklayan, bilgi kaynağı olarak öğrenciyi dersin hedefleri doğrultusunda yönlendiren ve eğiten temel dokümanlardır. Millî Eğitim Bakanlı̆̆ı Ders Kitapları ve Eğitim Araçları Yönetmeliği’nde (2016), "Kurulca, örgün ve yaygın eğitim ve öğretim kurumlarında okutulması uygun bulunan kitap.” şeklinde ders kitabının tanımı yapılmıştır. Çalık’a (2001) göre ders kitabı, tamamlayıcı öğretim materyalleri arasında yer alır ve öğretim sürecinde öğrenme yaşantılarına kaynaklık eden öğretmenin en önemli yardımcısıdır. Tanımlarda da vurgulandığı gibi ders kitapları eğitim ve öğretimin vazgeçilmez unsurları arasında yer almaktadır. Ders kitaplarının içeriği dersin özelliği, eğitim programının hedeflerine uygunluğu, öğretme-öğrenme süreci boyunca kullanılacak ölçme ve değerlendirme boyutlarına uygunluğu bakımından kabul görür bir şekilde hazırlanmış olmalıdır. Tüm bu özellikler gözetilerek hazırlanan ders kitapları, hem öğretmenlerin öğretme süreçlerinde vazgeçilmez bir araç hem de öğrenme sürecinde öğrencilerin temel başvuru kaynağıdır.

Eğitim ve öğretim faaliyetlerinin etkililiğini artırmak, öğrencilerini sınavlara hazırlamak isteyen öğretmenler ders kitaplarının yanı sıra yardımcı kaynakları da kullanmaya başlamışlardır. Binbaşıŏ̆lu (1973: 214), yardımcı kitapları "Ders kitaplarında verilen konuların hepsini veya bir kısmını daha ayrıntılı olarak işleyen kitaplardır.” şeklinde ifade ederken Güngör ve Çavuş (2015: 253), yardımcı kitapları, "Ders kitaplarının yanında kullanılan, konuları ayrıntılı inceleyen, daha fazla örnek ve soru içeren kitaplar.” şeklinde tanımlamaktadır. Yardımcı kitaplar kullanım amacı açısından bakıldığında

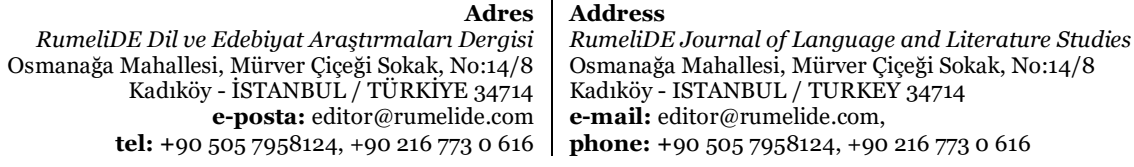


günümüzde kaynak kitap olarak ifade edilmektedir. Ders kitapları sık kullanılan eğitim materyallerinden biri olmakla birlikte öğretim programlarının hedeflediği kazanımları yüzeysel olarak ele alan, verilen kazanımların pekiştirilmesi için yeteri kadar etkinlik ve faaliyetleri içermeyen ders kitapları, öğretmen ve öğrencileri farklı kaynak arayışına yönlendirmektedir. Altun, Arslan ve Yazgan (2004), yaptıkları çalışmada ders kitaplarının kullanım sıklığının geçmişe göre azaldığını tespit etmişlerdir. 2018 yılında MEB tarafından okullara gönderilen bir genelgeyle dağıtımı yapılan ders kitapları dışındaki diğer yardımcı materyallerin öğrencilere aldırılmaması yönünde bir karar alınmıştır (MEB, 2018). Bu genelgeyle öğretmenlerin ders kitaplarına bağlı kalmaları istenmiş olsa da yardımcı kaynak kullanımı çeşitli nedenlerle devam etmektedir. Ders kitaplarının dil bilgisi etkinliklerinin yetersizliği, ders kitabının tek başına yetmediği düşüncesi (Çă̆, 2020); ders kitaplarının öğrencileri sınava hazırlama noktasında eksik olması (Katipoğlu ve Katipoğlu, 2016; Yılmaz, 2020); yardımcı kitapların öğrencilerin başarılarına olumlu etkisi olması (Güngör ve Çavuş, 2015; Haşıloğlu, Güler ve Durmaz, 2020) gibi sebepler öğretmenleri yardımcı kaynak kullanma nedenleri olarak ifade edilmektedir. Bu durum yardımcı kaynak ve sınavlara hazırlık kitaplarının üretim oranlarına da etki etmiştir. Türkiye Yayıncılar Birliği’nin 2019 yılına ait kitap pazarı raporuna göre Türkiye' de özellikle Covid-19 salgını nedeniyle kitap üretimi azalsa da yardımcı kaynak ve sınavlara hazırlık kitaplarının üretimi geçen ylla göre \%6,12 artarak, bu kaynaklar, toplam kitap üretiminde \%53,96'llk payla sektördeki liderliğini korumuştur (TÜRKYAYBİR, 2019).

Alan yazında yardımcı kaynak kullanımının öğrenci başarısına etkisini, ders kitaplarının yardımcı kitaplar karşısındaki eksikliklerini, yardımcı kaynak kullanmak konusunda öğretmen görüşlerini konu alan çalışmalara rastlanılmıştır. Çağ (2020), Öztürk (2019), Yılmaz (2020), Haşıloğlu, Güler ve Durmaz (2020), Taş ve Minaz (2018), Katipoğlu ve Katipoğlu (2016), Güngör ve Çavuş (2015) yardımcı kaynak kullanımına yönelik çalışmalar yürütmüşlerdir. Çağ (2020) tarafından Türkçe öğretmenleriyle yürütülen çalışma sonuçlarına göre araştırmaya katılan öğretmenlerin \%66’sı ders kitabı yanında kaynak kitap da kullanmaktadır. Öztürk'ün (2019) yaptığı çalışmada Türkçe öğretmenlerinin Türkçe ders kitabına bağlılık durumları \%59,8 olarak belirlenmiştir. Yılmaz’ın (2020), sınıf öğretmenleri ile yürüttüğü çalışmasının sonuçlarına göre araştırmaya katılan öğretmenler yardımcı kaynakları içerik ve tasarım yönünden ders kitaplarından daha zengin bulduklarını ifade etmişlerdir. Ayrıca öğrencileri sınavlara hazırlama noktasında yardımcı kaynakların ders kitaplarından daha nitelikli olduğu sonucuna ulaşılmıştır. Haşıloğlu, Güler ve Durmaz (2020), sosyal bilgiler ve fen bilgisi öğretmenleriyle yürüttükleri çalışmalarında öğretmenlerin görsel zenginlik ve uygulama fazlalığının yer alması, konu tekrarı ile kalıcı öğrenme sağlaması, konu anlatımında önemli nokta vurgusu, anlaşılır bir dil kullanılması gibi sebeplerden öğrencilerine yardımcı kitap aldırdıkları sonucuna varmışlardır. Taş ve Minaz (2018) yardımcı kitaplar kullanımıyla ilgili öğretmen, veli ve öğrenci görüşlerine yer verdikleri araştırmaları sonucuna göre katılımcılar yardımcı kaynakların merkezi sınavlar için gerekli olduğunu, öğrenciler tarafından daha çok sevildiğini ve daha ilgi çekici bulunduğunu, konuları daha yalın ve öz olarak ele aldığını, ders kitaplarının sıkıcılığını giderdiğini, daha kaliteli ve kullanışlı olduğunu bu kaynaklarda daha fazla soru ve etkinlik bulunduğunu ifade etmişlerdir. Katipoğlu ve Katipoğlu (2016) tarafından yapılan araştırmada; matematik öğretmenlerinin büyük çoğunluğu ders kitaplarının örnek soru bakımından yetersiz olduğunu belirtmiştir. Bu nedenle öğretmenlerin ders kitapları dışında yardımcı kaynaklardan yararlandığı sonucu ortaya konmuştur.

Yardımcı kitaba ihtiyaç duyan öğretmenler bu ihtiyacın nedenlerini en iyi bilen paydaşlardan biridir. Ders kitaplarının yanında yardımcı kaynak kitapların kullanımı birçok yayınevinin bu alanda yayınlar hazırlamalarına imkân tanımaktadır. Bireysel farklılıklar nedeniyle öğrencilerin anlama, anlatma becerileri, ilgi, ihtiyaç ve eğilimleri birbirinden farklı olmaktadır. Benzer şekilde her sınıfın farklı bir

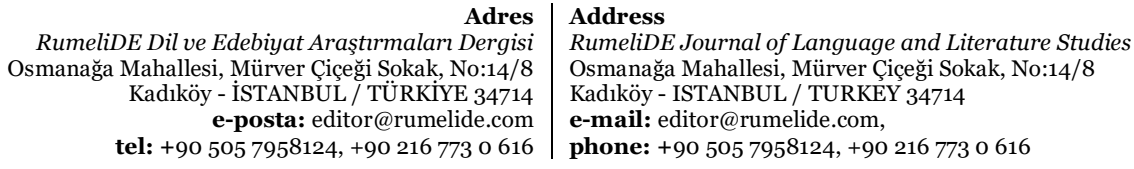


kültür ortamı vardır. Dolayısıyla sınıftaki gerçekliği en iyi bilen ve öğrencilerle ilgili en iyi ve anlamlı kararları vermesi beklenen kişiler öğretmenlerdir. Bu açıdan bakıldığında öğretmen özerkliği, mesleğin kendine özgü bazı koşul ve özelliklerinin, dolayısıyla öğrenme sürecinin ayrılmaz bir parçası olarak görülmektedir. Bununla birlikte ülkemizde öğretmen özerkliği sınırlı bir çerçevededir. Öğretim içeriğinden ders kitabına kadar süreç Milli Eğitim Bakanlı̆̆ tarafından belirlenmektedir (TEDMEM, 2015). Üretici bir beceri olan yazmanın bir amacı da bilgi ve deneyimleri aktarmaktır. Sistem içerisinde aktif rol alan öğretmenler son yıllarda bilgi ve deneyimlerini yardımcı kaynaklar hazırlayarak aktarmayı tercih etmektedir.

Ders kitaplarıyla birlikte yardımcı kitaplar da eğitim öğretimin önemli bir aracıdır. Eğitim öğretim sürecinde kazanımların edinilmesi ve sürecin değerlendirilmesinde ders kitapları ve yardımcı kitaplar öğretmenlerin en çok kullandığı materyallerin başında gelmektedir. Kaynak kitaplara duyulan ihtiyaç Milli Eğitim Bakanlığını da harekete geçirmiş ve 2020- 2021 eğitim-öğretim yllı için ilk defa 17,5 milyon öğrenci için ücretsiz yardımcı kaynak kitap dağıtma kararı alınmıştır (“Kitabım hep açı; okulda, evde, öğretmenimle, ailemle”, 2020). Eğitim öğretim süreci çok yönlüdür ve birçok paydaşı bulunmaktadır. Kaynak kitaplarla ilgili çalışmaların daha çok öğretmen sonrasında ise öğrenci ve veli görüşlerine yönelik olduğu görülmekle birlikte bu konunun başka bir paydaşı olan kaynak kitap yazarlarının görüşlerini yansıtan çalışmalara rastlanılmamıştır. Bu çalışmada MEB' e bağlı olarak çalışan ve kaynak kitap yazan Türkçe öğretmenlerinin kaynak kitap yazmaya neden yöneldikleri ve süreçle ilgili görüşleri derinlemesine incelenmiştir. Bu amaç doğrultusunda kitap yazarlarına aşağıdaki sorular yöneltilmiştir:

1. Türkçe öğretimine yönelik hazırladığınız kaynak kitabın içeriği hakkında bilgi verebilir misiniz?

2. Kaynak kitabınızı hazırlama gerekçeleriniz nelerdir?

3. Kaynak kitabı oluştururken ne gibi zorluklarla karşılaştınız? Bu zorlukları aşmak için neler yaptınız?

4. Oluşturduğunuz kaynak kitabın Türkçe öğretimine katkısı ile ilgili neler söyleyebilirsiniz?

5. Oluşturduğunuz kaynak kitaplarla ilgili nasıl dönütler aldınız, bu konuda neler söyleyebilirsiniz?

6. Aldığınız bu dönütler size ne gibi katkılarda bulundu, bu konuda neler söyleyebilirsiniz?

7. Oluşturulan kaynak kitapların öğrenci başarısına etkisi nedir?

8. Eklemek istediğiniz duygu ya da düşünceniz var mı?

\section{Yöntem}

$\mathrm{Bu}$ çalışma nitel araştırma yöntemlerinden olgu bilim (fenomenoloji) desenine uygun olarak tasarlanmıştır. Araştırma süreci Şekil 1'de verilmiştir.

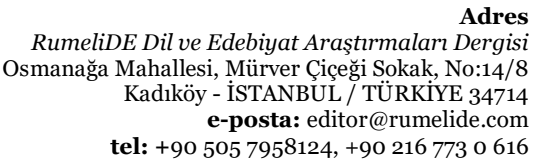

Adres
RumeliDE Dil ve Edebiyat Araşturmaları Dergisi Kadıköy - ISTANBUL / TÜRKIYE 347 tel: +90 505 7958124, +902167730616
Address

RumeliDE Journal of Language and Literature Studies

Osmanağa Mahallesi, Mürver Çiçeği Sokak, No:14/8

Kadıköy - ISTANBUL / TURKEY 34714

e-mail: editor@rumelide.com,

phone: +90 $5057958124,+902167730616$ 


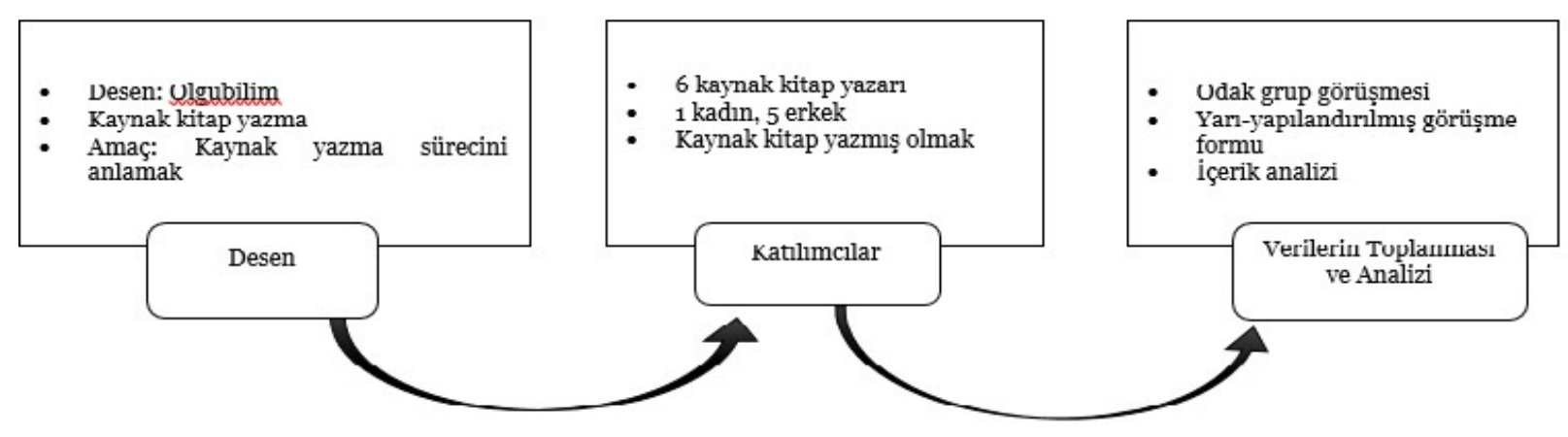

Şekil 1. Araştırma süreci

\section{Desen}

Olgu bilim, birkaç kişinin bir fenomen veya kavramla ilgili deneyimlerinin ortak anlamını tanımlayan bir nitel araştırma modelidir (Creswell, 2013, s.77). "Fenomenoloji, bir fenomenin bireylerin ya da belli bir grubun deneyimleri açısından tanımlanmasıdır." (Chirstensen, Johnson ve Turner, 2015:408). Saldana’ya (2011:7) göre fenomenoloji, şeylerin doğası ve anlamı üzerine yapılan çalışmalardır.

"Olgu bilim (fenomenoloji) deseni farkında olduğumuz ancak derinlemesine ve ayrıntılı bir anlayışa sahip olmadığımız olgulara odaklanmaktadır. Bize tümüyle yabancı olmayan aynı zamanda da tam anlamını kavrayamadığımız olguları araştırmayı amaçlayan çalışmalar için olgu bilim uygun bir araştırma zemini oluşturur." (Yıldırım ve Şimşek, 2016). Klave (1996)' e göre olgu bilim bir olgunun hem nasıl algılandı̆̆ını hem de ortaya çıkış biçimini aydınlatma amacı taşır. Olgu bilim araştırmalarında deneyime, deneyimin niteliğine yönelik çeşitliliği kavramaya ve ilgili olguya ait temel anlamları keşfetmeye çalışılır. Bu çalışmada kaynak kitap yazan Türkçe öğretmenlerinin kaynak kitap yazmaya ilişkin deneyimlerine dair görüşlerini anlamak, bu deneyimlerini derinlemesine incelemek amaçlandığ 1 için olgu bilim deseni kullanılmıştır.

\section{Katılımcilar}

Olgu bilim çalışmalarında katılımcı seçimi yapılırken çalışmada odaklanılan olguyu, durumu ya da deneyimi yaşamış olan ve yaşadıklarını araştırmacıya derinlemesine aktarabilecek kişiler seçilerek araştırma yapılmalıdır. Bu nedenle ölçüt örnekleme ya da kartopu örnekleme yoluyla katılımcı belirlenebilir (Karakoç, 2019). Bu çalışmada araştırmaya katılacak kaynak kitap yazarlarının seçiminde amaçlı örnekleme yöntemlerinden biri olan ölçüt örneklem tekniğine başvurulmuştur. Ölçüt örneklem tekniğinde "Gözlem birimleri belli niteliklere sahip kişiler, olaylar, nesneler ya da durumlardan oluşturulabilir. Bu durumda örneklem için belirlenen ölçütü karşılayan birimler (nesneler, olaylar, vb.) örnekleme alınırlar (Büyüköztürk, Çakmak, Akgün, Karadeniz ve Demirel, 2016:92).” Ölçüt örnekleme katılımcıların hepsi olguyu deneyimleyen insanlardan oluştuğunda işe koşulabilir.

Olgu bilim çalışmalarında derinlemesine görüşmeler yapmak gerektiğinden genellikle 10 veya daha az katılımcı ile çalışmalar yürütülür (Eddles-Hirsch, 2015; Karakoç, 2019) Bu çalışmada da yazarların ulusal çapta yayın yapan bir yayınevinde kaynak kitabı yazarı olmaları ve aktif olarak MEB bünyesinde Türkçe öğretmeni olarak çalışıyor olmaları ölçüt olarak belirlenmiştir. Bu ölçütleri sağlayan ve araştırmaya katılmak için gönüllü olan 6 kaynak yazarı çalışma grubuna dâhil edilmiştir. Araştırmaya katılan kaynak kitabı yazarları ile ilgili özellikler Tablo 1'de gösterilmiştir.




Tablo 1. Kaynak kitabı yazarlarının demografik özellikleri

\begin{tabular}{lllll}
\hline Yazar & Cinsiyet & Kıdem Yılı & Mezun Olunan Bölüm & Ĕ̆itim Düzeyi \\
\hline Y1 & Erkek & 16 & Fen-Edebiyat Fak. & Lisans \\
Y2 & Erkek & 16 & Fen-Edebiyat Fak. & Y. Lisans \\
Y3 & Kadın & 8 & Türkçe Öğrt. & Lisans \\
Y4 & Erkek & 18 & Türkçe Öğrt. & Lisans \\
Y5 & Erkek & 10 & Türç̧e Öğrt. & Lisans \\
Y6 & Erkek & 21 & Edebiyat Öğrt. & Lisans \\
Toplam & & & & 6
\end{tabular}

Tablo 1'de de görüldüğü gibi çalışmaya katılan Türkçe dersi kaynak kitap yazarlarının 1’i kadın, 5’i erkektir. Katılımcıların MEB'deki çalışma sürelerine bakıldığında 8 ila 21 yıl arasında bir kıdeme sahip oldukları görülmektedir. Mezun olunan bölüm incelendiğinde 3 katılımcının Fen- Edebiyat Fakültesi mezunu, 3 katılımcının da Türkçe Öğretmenliği mezunu olduğu anlaşılmaktadır. Ayrıca eğitim düzeyleri incelendiğinde sadece 1 kişinin Yüksek Lisans mezunu olduğu görülmektedir.

\section{Verilerin toplanması}

Olgu bilim araştırmalarında birçok veri toplama aracı kullanılmakla birlikte deneyimin anlamı hakkında katılımcılarla derinlemesine konuşmak için sıklıkla yüz yüze görüşmeler ile veri toplanır (Bloor ve Wood, 2006; Gürbüz ve Şahin, 2016:113). Olgulara ilişkin yaşantıları ve anlamları ortaya çıkarmak için görüşme, araştırmacılara etkileşim, esneklik ve sondalar yoluyla olguyu irdeleme özellikleri sunar (Yıldırım ve Şimşek, 2016: 71). Bir olgu bilim araştırması olan bu çalışmada da verilerin toplanmasında katılımcıların deneyimleri anlamak için görüşmeden yararlanılmıştır.

Araştırmada kullanılan görüşme soruları hazırlanırken önce alan yazın taraması yapılmış ve taslak form oluşturulmuştur. Taslak form Türkçe eğitimi alanında bir, eğitim bilimleri alanında iki öğretim üyesi ve bir Türkçe öğretmeni tarafından incelenmiştir. Uzman görüşleri doğrultusunda bazı maddeler yeniden düzenlenmiş ve "Eklemek istediğiniz duygu ya da düşünceniz var mı?” Sorusu forma dâhil edilmiştir. Uzman görüşleri sonucunda son halini alan form sekiz sorudan oluşmaktadır. Maddeler yardımcı kitapların içerikleri, hazırlanma süreçleri, geri dönütler kapsamında hazırlanmıştır.

Görüşmeler çevrimiçi iletişim araçları kullanılarak gerçekleştirilmiş, araştırma ile ilgili hazırlanmış yarı yapılandırılmış görüşme formunda yer alan sorulara katılımcıların cevap vermeleri istenmiştir. Katılımcılara herhangi bir süre sınırı konmamıştır. Görüşmeye başlanmadan önce katılımcılara çeşitli açıklamalarda bulunulmuştur. Görüşmenin kayıt altına alınacağı, katılımcı isimlerinin gizli kalacağı, elde edilen verilerin amacının dışında kullanılmayacă̆ı, katılımcılara ait görüşler aktarılırken kod isimler kullanılacağı katılımcılara sözlü olarak bildirilmiştir. Görüşmeler bireysel olarak katılımcıların zamanlamasına uygun olacak şekilde toplamda 7 gün içinde yapılarak araştırma verileri toplanmıştır.

\section{Verilerin analizi}

Kaynak kitap yazarlarıyla yapılan görüşmeler sonucunda elde edilen veriler içerik analizi tekniğiyle çözümlenmiştir. "İçerik analizinde temelde yapılan işlem, birbirine benzeyen verileri belirli kavramlar ve temalar çerçevesinde bir araya getirmek ve bunları okuyucunun anlayacağı bir biçimde düzenleyerek yorumlamaktır.” (Yıldırım ve Şimşek, 2016, s. 242).”

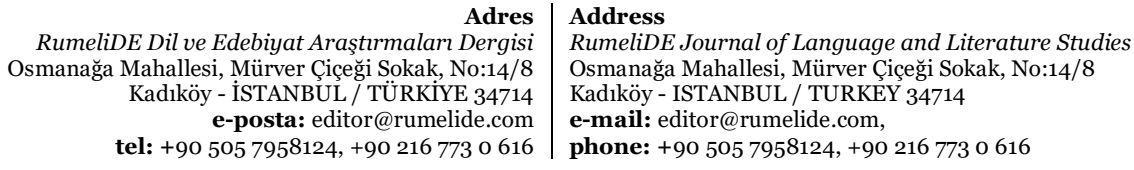


Kaynak kitap yazarları ile yapılan görüşmeler izin alındıktan sonra ses kaydına alınmıştır. Ses kayıtları daha sonra bilgisayar ortamına aktarılarak metin haline getirilmiştir. Oluşturulan metinlerin eksiksiz olması için ses kayıtları tekrar dinlenerek oluşturulan metinlere son halleri verilmiştir. Sorulan soruların cevapları 17 sayfalık ham veri haline getirilmiştir. Elde edilen veriler araştırmacılar tarafından birbirlerinden bağımsız bir şekilde değerlendirilerek kodlamalar yapılarak temalar haline getirilmiştir. Daha sonra benzerlikler ve farklılıklar üzerinde tartışma yapılarak son şekli verilmiştir. Böylece analiz sürecinde yanlılı̆̆ gidermek ve araştırmanın geçerlik ve güvenirliği sağlanmaya çalışılmıştır.

Nitel araştırmalarda geçerlik ve güvenirliğin sağlanabilmesi adına kullanılabilecek farklı yöntemler bulunmaktadır (Creswell, 2013). Çalışmada geçerliğin sağlanması adına görüşme soruları alan yazın taranarak hazırlanmış ve dört uzmanının görüşüne sunulmuştur. Sorular uzmanların önerileri göz önünde bulundurularak gözden geçirilmiş ve yapılan öneriler doğrultusunda gerekli düzeltmeler yapılarak görüşme formuna son biçimi verilmiştir. Araştırmada güvenirliğin sağlanması adına görüşmelerde katılımcıların onamıyla ses kaydı alınmıştır. Görüşmeler yazıya aktarıldıktan sonra araştırmada güvenirliği sağlamak için Miles ve Huberman modelinde içsel tutarlılık olarak adlandırılan ve kodlayıcılar arasındaki görüş birliği olarak kavramsallaştırılan benzerlik formülü kullanılmıştır. Araştırmacılar dışında nitel araştırma konusunda deneyimli bir alan uzmanı tarafından veriler okunarak tekrar kodlanmıştır. Okuyucular arası görüş birliği \% 89 olarak hesaplanmıştır. İçsel tutarlılı̆̆ı veren kodlama denetimine göre kodlayıcılar arası görüş birliğinin en az \% 80 olması beklenmektedir (Miles ve Huberman, 2016; Patton, 2014). Sonuç olarak yapılan analizin güvenilir olduğu ifade edilebilir. Verilerin analizinden elde edilen bulgularda görüşmelerden doğrudan alıntılara yer verilerek araştırmanın güvenirliği desteklenmiştir.

\section{Bulgular}

Görüşmeler sonucunda elde edilen veriler içerik, gerekçe, karşılaşılan zorluklar, çözüm yolları, Türkçe öğretimine katkısı, dönütler, öğrenci başarısına etkisi ve görüşler başlıkları altında toplanmıştır. Her bir başlık grafik düzenleyiciyle gösterilerek başlıklar için katılımcıların örnek cümlelerine yer verilmiştir.

\section{Yazarların kitap içeriklerine ilişkin görüşleri}

Kaynak kitap yazarları kitaplarını oluştururken farklı türde içeriklere yönelik yayınlar hazırladıklarını ifade etmişlerdir. İçerik oluştururken kitaplarını ihtiyaca, öğrencilere farklı soru tarzlarında hazırlanmış kaynak kitaplarla hitap etmeye, kazanımların farklı şekilde pekiştirilmesine gayret gösterdiklerini ifade etmişlerdir. Bu ifadeler Şekil 2'de gösterilmiştir.

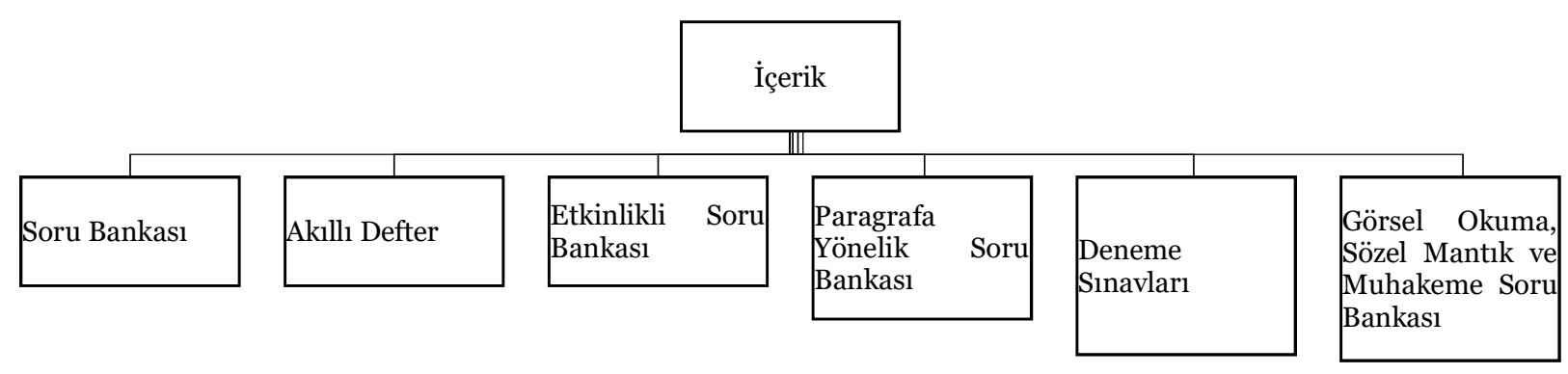

Şekil 2. Kaynak kitapların içerikleri

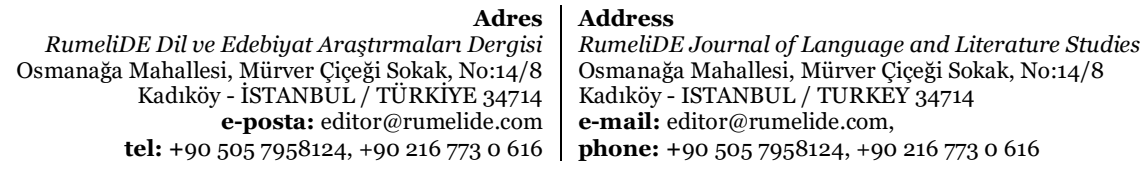


Buna göre yazarlar soru bankası, akıllı defter, etkinlikli soru bankası, paragrafa yönelik soru bankası, deneme sınavı, görsel okuma sözel mantık ve muhakeme soru bankası içeriklerine sahip kitaplar hazırladıklarını ifade etmişlerdir. Bu içerikleri seçerken MEB'e bağlı kurumlarda çalıştıkları için ders kitaplarının yetersiz olduğu kısımları görmekte, ders kitaplarının hangi noktalarda eksik olduğunu fark etmekte ve öğrencilerin akademik yeterliliklerini gözlemlemektedirler. Kaynak kitapların içeriklerini oluştururken yetersiz kısımları, eksik olan noktaları ve öğrencilerin akademik yeterliliklerini göz önüne aldıklarını ifade etmişlerdir.

Yazarların, kitapların içeriklerine yönelik görüşlerinden bazıları aşă̆ıda verilmiştir:

"Türkçe öğretim programında öğrencilere kazandırlması gereken kazanımlara uygun olarak farkl kaynaklar hazırladı." (Y1).

"Hazırladığımız kaynak kitaplar daha çok soru bankası, etkinlikli konu anlatımı, yaprak test veya deneme şeklinde olmakta. Bu sürece göre değişmekte.” (Y3).

"Akıllı defter kitaplarımızın ilk amacı konuyu öğrenciye öğretmektir. Öğrenilen konunun pekiştirilmesi için her konu başlğından sonra örneklere, stra sizde bölümlerine etkinliklere ve her ünite sonunda da yazılya hazırlk bölümüne ve test sorularma yer verdik. Bu pekiştirmelerin ardından öğrenci kademeli olarak bilgiyi öğrenir.” (Y4).

"Türkçe kitaplarmızda öğrencilerimizin üst düzey beceri geliştiren metin, tablo, grafik ve görsel anlama dayah soruları merkeze alan bir yaklaşım benimsedik.” (Y5).

“... tane tane serisi. Bu daha çok öğrencilerin derste öğrendiği yeni konuları pekiştirme amaçh bu yüzden etkinliklerle ilerliyor.” (Y6).

\section{Yazarların kaynak kitap hazırlama gerekçelerine ilişkin görüşleri}

Kaynak kitap yazarları kitaplarını oluşturma gerekçelerini; MEB ders kitaplarının yetersizliği, seviyeye göre hazırlanmış kaynak kitap olmaması ve maddi kaynak sağlama şeklinde ifade etmişlerdir. Özellikle MEB ders kitaplarının yetersiz olması başlı̆̆ı altında a) Sınavlara yönelik soru sayısının yetersiz olması, b) Mevcut soruların yeterli nitelikte olmaması, c)Soruların mevcut sınav sistemine yönelik olmaması alt başlıklarında görüşlerini belirtmişlerdir. Bu gerekçeler Şekil 3’te gösterilmiştir.



Adres 8 (1)

Address

RumeliDE Journal of Language and Literature Studies

Osmanağa Mahallesi, Mürver Çiçeği Sokak, No:14/8

Kadıköy - ISTANBUL / TURKEY 34714

-mail: editor@rumelide.com,

phone: +90 5057958124 , +90 2167730616 


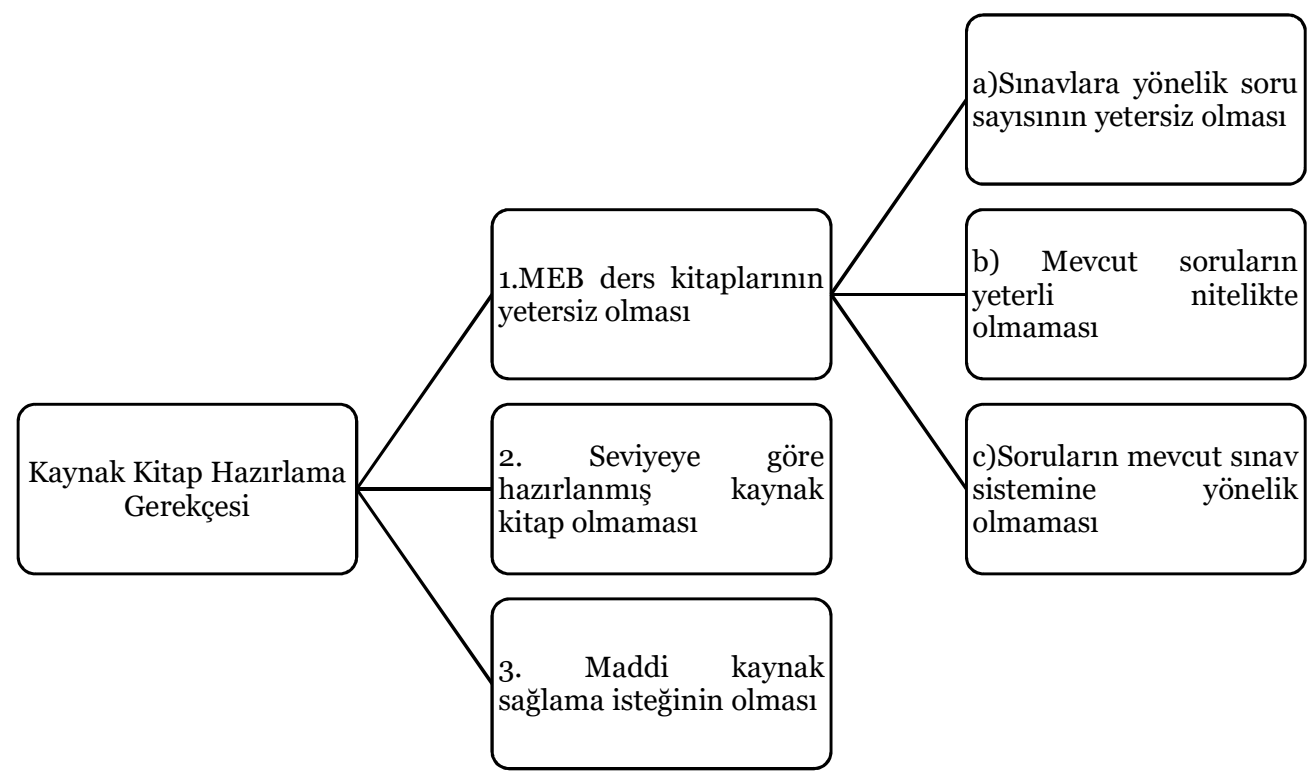

Şekil 3. Kaynak kitapların hazırlanma gerekçeleri

Kaynak kitap yazarları, yapılan görüşmelerde MEB ders kitaplarının yetersizliği üzerinde özellikle durmuşlardır. Eğitim ve öğretimin temel materyali olan ders kitaplarının özellikle öğrencileri sınava hazırlama noktasında eksik kaldığı, ders kitaplarının içerisinde yer alan soruların hem nitelik hem de nicelik bakımından sınava hazırlanan öğrencilere yetersiz geldiğini ifade etmişlerdir.

Ders kitaplarında yer alan sorular ile seçme sınavlarında sorulan sorular arasındaki paralelliğin yetersiz olduğu, ders kitaplarında yer alan soruların bilgiyi ölçme basamağından öteye gitmediği görüşmede elde edilen verilerin analizinden anlaşılmıştır. Sınavlarda öğrencilere yönelik sorulan sorularda ise verilen bilgiyi yorumlama, yeni çıkarımlarda bulunma, uygulama, analiz ve sentez basamaklarına uygun sorular sorulduğu ifade edilmiştir.

Yapılan görüşmeler neticesinde kaynak kitapların öğrenci seviyelerine uygun hazırlanmaması da kaynak kitap hazırlama gerekçelerinden birisi olmuştur. Hazırlanan kaynak kitapların ya kolay sorulardan oluştuğu ya da zor sorulardan oluştuğu belirtilmiştir. Sorular oluşturulurken öğrencilerin seviyelerinin gözetilmediği vurgulanmıştır.

Maddi kaynak sağlama, bir başka kaynak kitap hazırlama gerekçelerinden biridir. Kaynak kitap yazarları; verilen emeğin, harcanan zamanın, gösterilen çabanın bir maddi karşılığının olması gerektiği ifade etmişlerdir.

Yazarların kitap hazırlama gerekçelerine yönelik görüşlerden bazıları aşağıda verilmiştir:

"Kaynak kitaplarımızı hazırlama gerekçemiz Millî Eğitim Bakanh̆ğını biliyorsunuz, ders kitapları merkezi sinavlara hazırlk konusunda son derece yetersiz.”(Y1).

"Merkezi sınavlarda öğrencilerin muhatap oldukları soru tarzları ile MEB'in dağıttı̆̆ ders kitaplarındaki soru tarzları arasında maalesef çok büyük bir uçurum var. Sadece o kitaplarla sinava hazırlanan bir öğrencinin sınavda başarıyı yakalaması mümkün değil.” (Y2).




"Genellikle sinıf ortamında öğrencilere kaynak önerisinde bulunurken, öğrencilerin eğitim düzeyi daha doğrusu hazırbulunuşluk seviyeleri bizim için önemli oluyor. Baktığımız zaman kaynak kitaplar genellikle çok kolay ya da çok zor seviyelerde hazırlanmış oluyor. Kaynak kitapları hazırlarken biz her sinıfta, her düzeyde öğrencinin olduğu gerçeğinden yola çıarak kaynaklar hazırlıyoruz.” (Y3).

"Kaynak kitaplar ders kitaplarını sinavlara hazırlık noktasında eksik kaldığı yerlerde en önemli başvuru kitapları olarak büyük bir öneme sahiptir." (Y4).

“... tüm çocuklarımıza merkezi sınavda yardımcı olmak, onların başarıya ulaşmasına katkı sağlamaktır.”(Y5).

\section{Yazarların karşılaşılan zorluklara ilişkin görüşleri}

Kaynak kitap yazarlarının kaynak kitap hazırlarken karşılaşılan zorluklarla ilgili görüşleri analiz edildiğinde; kazanımların sınırlarının net olmaması, kazanımların sınıf seviyesine göre ayrılmaması/ kazanımların çoğunun her sınıfta aynı olması, yayınevlerinin öğretim programının içeriğinin dışında soru istemesi, öğretim programlarının sık değişmesi, TDK'nin yazım kurallarının tutarsız olması, görsel sorularda dizgi sorununun yaşanması ve telif problemlerinin yaşanmasına yönelik görüş belirttikleri görülmüştür. Bu görüşler şekil 4'te gösterilmiştir.

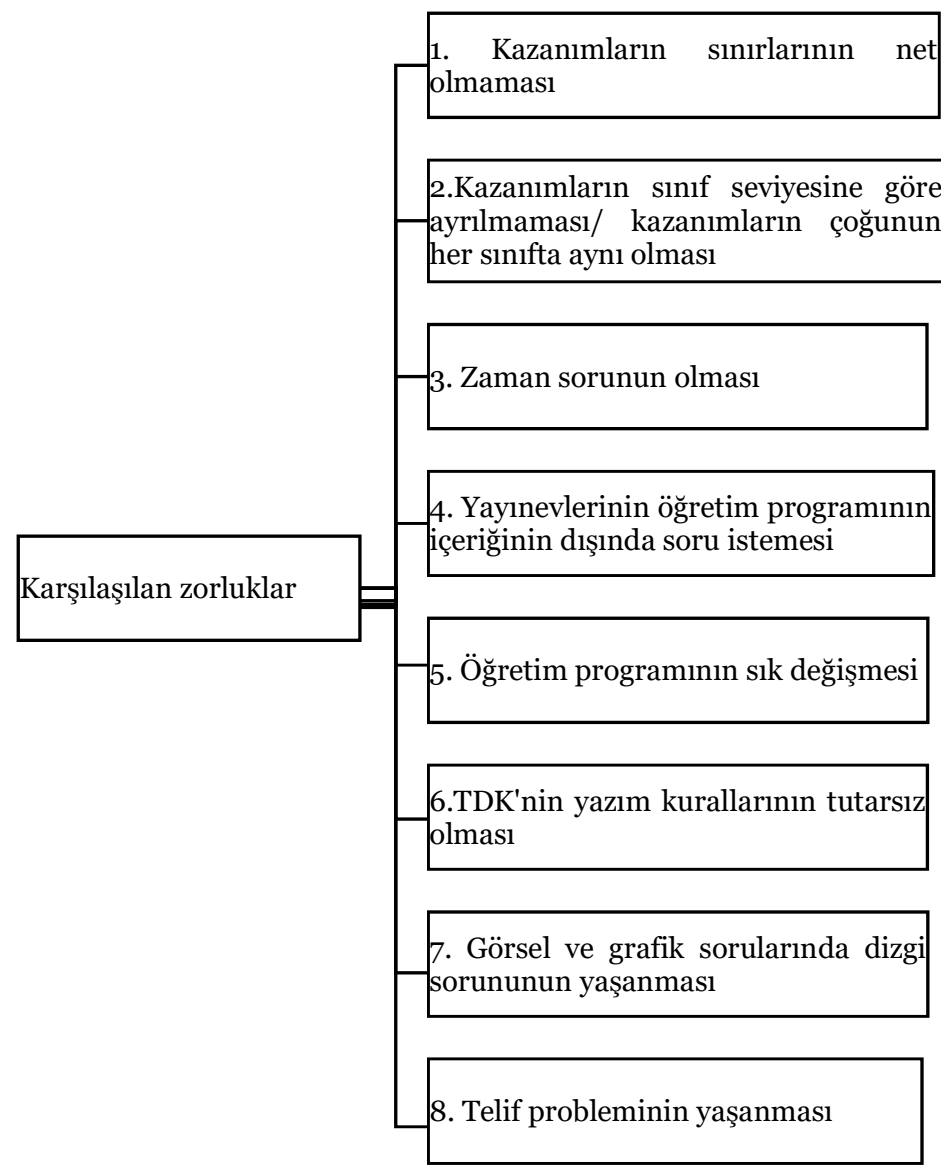

Şekil 4. Kaynak kitap hazırlanırken karşılaşılan zorluklar

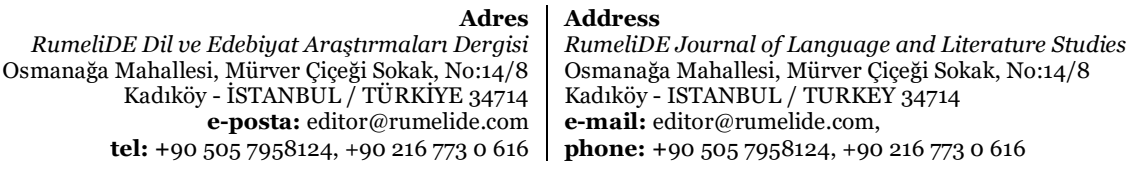


Kaynak kitap yazarları hazırladıkları kitap içeriklerine göre farklı türde zorluklarla karşılaşmaktadırlar. Bu zorluklara ait yazar görüşlerinden bazıları aşă̆ıda verilmiştir:

"Kaynak kitaplarımızı hazırlarken pek çok zorlukla karşılaşıyoruz. Ancak yaşadığımız en büyük zorluğun Türkçe öğretim programında bazı kazanımların net olmaması olduğunu söyleyebilirim. Öyle ki bazı kazanımlar ucu çok açık şekilde verilmiş ve bu o konunun çok derinlemesine anlatabileceğini, çok yüzeysel biçimde anlatabileceğini bize gösteriyor. Kazanımın sinırlarının net olmaması bizi oldukça zora sokuyor.”(Y1).

"Benim karşılaştığım en önemli zorluk öğrencilerin seviyelerine uygun metin bulmak ya da oluşturma sorunu, diyebilirim. (Y2).

"Yardımcı kaynak oluştururken bu kaynağı basan yayınevinin müfredat karşısındaki tutumu da önemli olabiliyor. Sinavda çımmasa dahi çocuk sorumlu olmasa dahi o sinıf düzeyindeki kazanım olmasa dahi ne olur ne olmaz bundan da soru soralım şeklinde bazı yanlış algılar kaynak kitapları şekillendiriyor maalesef" (Y3).

"Eskiden bir müfredat 10-15 sene kullanllrd. Son yıllarda ise nerdeyse her sene müfredat değişiklikleri yapıldı. Müfredat değişmesi demek bütün yardımcı kitapların da güncellenip yeniden hazırlanması demektir. Sürekli değiştirilen müfredata göre kitapları güncellemek bizleri çok yoruyor. Özellikle TDK'nin birçok yazım kuralında sürekli değişiklik yapması bizi en fazla zorlayan konudur. Örneğin geçen yıl bir kurala göre yazdığımız sorunun kuralında değişiklik yapıldığında bizim kitaptaki o soru önceki kurala göre doğru yeni kurala göre yanlş̧ olmuş oluyor. Bu gibi durumlar bizi çok zor durumlara düşürmektedir.” (Y4).

"Dizgi aşaması en zor süreçlerden bir tanesi. Kitap dizgiden geldiğinde dizgi kaynakh soruyu yanlış hale getiren birçok hata çıkabiliyor.” (Y5)

"Bir soru oluşturmak için aldığım bir kaynağın telif problemi en büyük problemimiz bizim (Y6)."

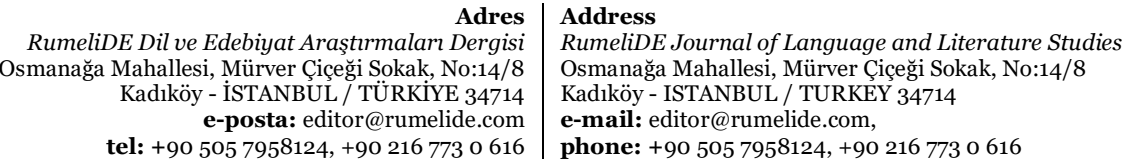




\section{Yazarların karşılaşılan zorlukların çözüm yollarına ilişkin görüşleri}

Karşılaşılan zorluklara ilişkin kaynak kitap yazarları çözüm yolu olarak şunları ifade etmişlerdir; kazanımların dışına çıkılmamaya gayret edilmesi, alan uzmanlarından görüş alınması, telif sorunu nedeniyle yazarın kendinin metin yazması, çalışma takviminin oluşturulması ve yayınevlerine standart getirilmesi. Karşılaşılan zorluklara ilişkin çözüm yolları Şekil 5’te gösterilmiştir.

Yayınevlerine standart getirilmesi ile ilgili çözüm yolu görüşmenin duygu ve düşünceler bölümünde ifade edilmiştir. Bir nevi çözüm yolu olduğu için bu bölüme alınmıştır. Yazarların çözüm yolları ile ilgili görüşlerinden bazıları aşă̆ıda verilmiştir:

"Çocukların seviyelerine uygun metin bulmak için bol okuma yapmak gerekli. Çoğunluğunu kendimiz yazmaya gayret ediyoruz metinlerimizi.” (Y2).

"Kitabın dizgili halini kontrol ettikten sonra birkaç Türkçe öğretmen arkadaşıma gönderip farkh

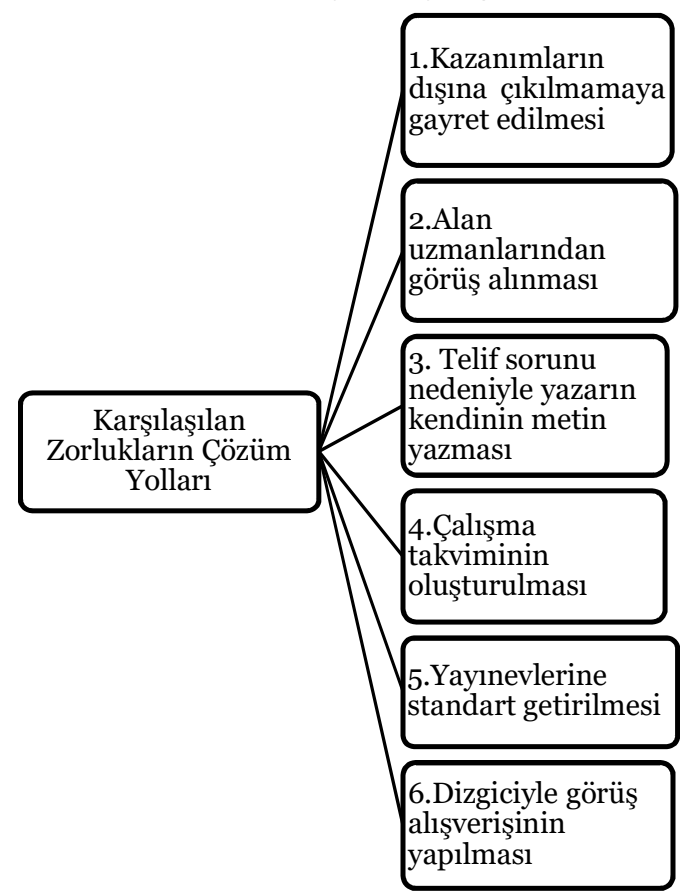

Şekil 5. Kaynak kitap yazarken karşılaşılan zorlukların çözüm yolları

gözlerle bir kez daha incelenmesini sağlyyorum.” (Y5).

"Ben büyük çoğunlukla özellikle olay yazılarımı kendim yazıyorum. Dolayısıyla bu engeli de bu şekilde aşıyorum.” (Y6).

"Bir kontrol mekanizması belki bir standart özellikle yayınevlerine getirilecek bir standart bunu çok daha olumlu yönde etkileyecektir.” (Y3).

"Millî Ĕ̆itim Bakanlı̆̆ın aslında bir düzenleme yapması gerektiğini düşünüyorum. İnşallah önümüzdeki yıllarda bu konularda bir çalışma yapıllr. Bu iş biraz daha derli, toplu biraz daha bilinçli,

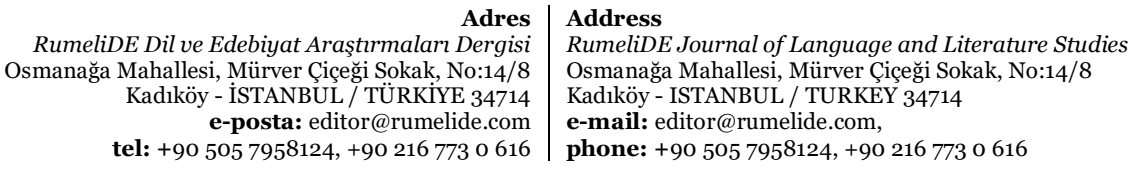


tamamen ticareti ön plana çıkan şekilde değil, eğitimi öğretimi ön plana çıkaran şekilde yeniden düzenlenir diye düşünüyorum.” (Y1).

\section{Yazarların kaynak kitapların Türkçe öğretimine katkısına ilişkin görüşleri}

Kaynak kitap yazarları ile yapılan görüşme çözümlendiğinde kaynak kitapların Türkçe öğretimine katkısına yönelik kaynak kitap yazarları şu görüşleri ifade etmişlerdir; ihtilaflı konularda öğretmenlere rehberlik etmesi, kazanımların kavranmasında ve pekiştirilmesinde katkı sağlaması, seviyelere göre hazırlanmış kaynakların öğrenciyi derse karşı motive etmesi, mesleğin içinde olan yazarların sorunları daha doğru tespit etmesi ve çözüm yolları bulması, konuların öğretilmesini kolaylaştırması ve öğrencilerin üst düzey düşünme becerilerine katkı sağlaması. Hazırlanan kaynak kitapların Türkçe öğretimine etkisi Şekil 6’da gösterilmiştir.

Yazarların kaynak kitapların Türkçe öğretimine ilişkin görüşlerinden bazıları aşağıda verilmiştir:

"Türkçe de kimi zaman bilim insanlarını bile ihtilafa düştüğü konular var. Bu konularda çok detaya girmeden genel görüşü yani birçok bilim insanını kabul ettiği temel görüşü biz de kabul ederek onu baz alarak kaynaklarımızı hazırlamaya çalışıyoruz. Kitaplarımızın da bu anlamda Türkçe öğretimine büyük bir katkısı olduğunu düşünüyoruz. Türkçe dersinde ihtilafl olabilecek ya da yaygin bir şekilde yanlış bilinen şeyler üzerinde son derece etkili olduğumuzu düşünüyoruz.”(Y1).



Şekil 6. Kaynak kitapların Türkçe öğretimine katkısı

"Öğrencilerin kazanımları daha iyi kavramalarna ve konuyu daha iyi öğrenmelerine yardımcı oluyor. En büyük katkı bence bu. Malumunuz öğrenmede bol tekrar, sürekli tekrar, sık tekrar çok önemli. Çocuklar farkl kaynaklardan farkh soruları çözerek, farklı soru tarzlarnda gelen soruları çözerek konu eksikliklerini, kazanımları kavramadaki güçlükleri aşmış oluyorlar.” (Y2)

“Çocuğun kendi başarısını görebildiği, çok zorlanmadığı bir kaynağı oluşturmak çocukta Türkçeyi yapabileceğine dair bir inanç oluşturuyor. Türkçe için çocuklarm en büyük ön yargllarmdan bir tanesi uzun metinler, uzun metinleri gördükleri soruları direkt yapamam şeklinde bir düşünceyle yaklaşıyorlar. Bunu aşabilmek için seviyelendirilmiş metinler, yani uzunluklarn seviyelendirilmiş metinler kullanıyoruz ve bu da çocuklar için olumlu yönde etki ediyor.”(Y3).

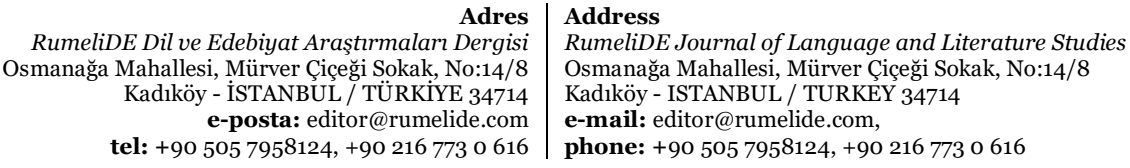

Adres
RumeliDE Dil ve Edebiyat Araştırmaları Dergisi el: +90 505 7958124, +90 2167730616

phone: +90 505 7958124, +90 2167730616 
"Okulda çalışan bir öğretmenin kaynak kitap çıkarması eksikleri bilip buna yönelik çalışma yapması bakımından olukça değerli bir çalışmadır. Türkçe öğretimine olumlu katkılar sağladığı fikrindeyim. Öğrenciye bol bol alıştırma firsatı sunuyor.” (Y4).

"Önceki sorular oku ve işaretle yönelikti. Artık yeni sistemde çocuk okuyacak düşünecek ve bir sonuca varacak, düşünmeden işaretlemeyecek.” (Y6).

\section{Yazarın kitaplara yönelik alınan dönütlere ilişkin görüşleri}

Kaynak kitap yazarlarının kitaplara ilişkin dönütleri öğretmen ve öğrenci başlı̆̆ı altında sorulmuş, yazarlardan dönütlere ilişkin bilgiler istenmiştir. Görüşme çözümlendikten sonra gelen dönütlerin olumlu ve olumsuz dönütler olarak iki başlık altında toplandığı görülmüştür. Olumlu dönütler; öğrencilerde Türkçe dersine karşı olumlu tutum geliştirmesi, konu ve/veya kazanımlarla ilgili eksiklerin bildirilmesi ve konuların öğrenilmesini kolaylaştırılması şeklinde ifade edilmiştir. Olumsuz dönütler; soruların öğrenci seviyelerine uygun olmaması, soruların anlaşılırlığına yönelik sorunlar olması, soruların daha basit hazırlanma isteğinin olması, kitap ücretlerinin yüksek olması, kaynak kitapların görsel unsurlarının geliştirilmesine yönelik olarak ifade edilmiştir. Yazarların olumsuz dönütlere ilişkin görüşleri Şekil 7’de verilmiştir.

Şekil 7. Kaynak kitaplara ilişkin alınan olumlu ve olumsuz dönütler

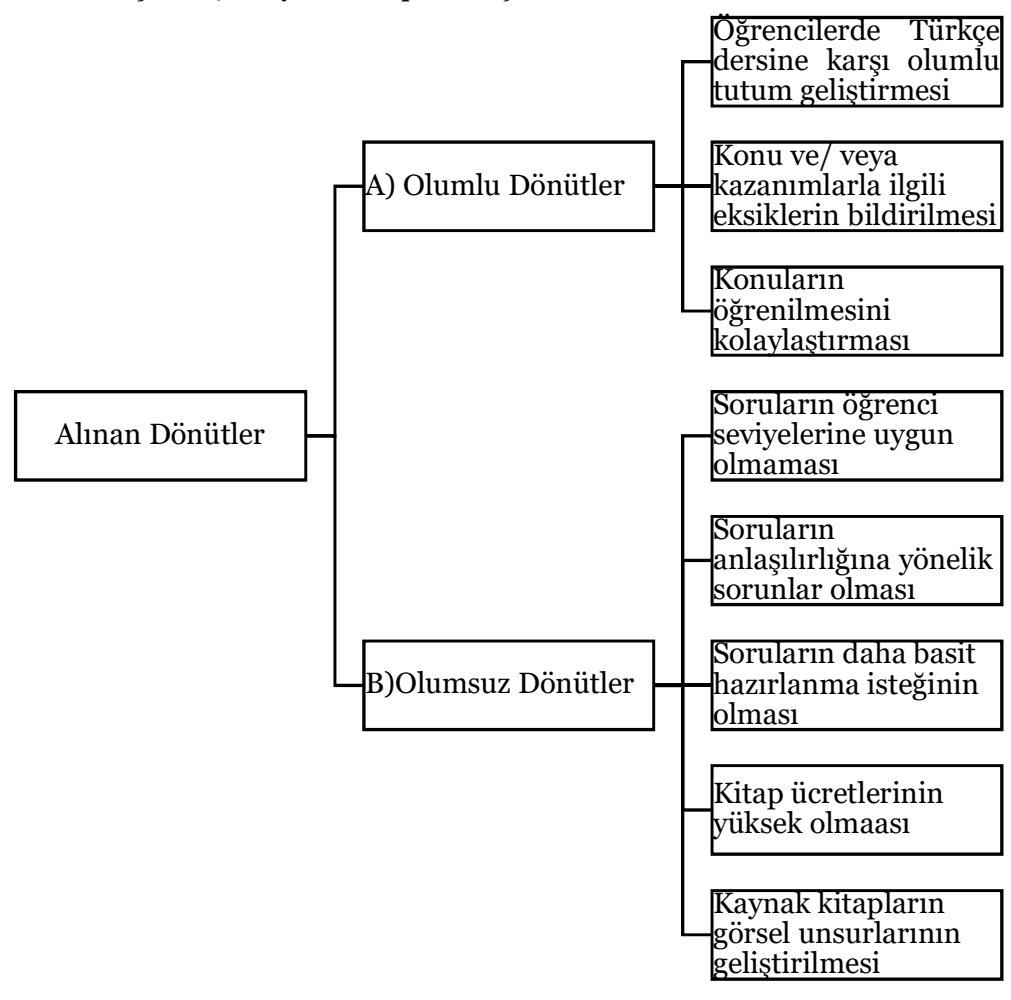

Şekil 7. Kaynak kitaplara ilişkin alınan olumlu ve olumsuz dönütler

Yazarların olumlu dönütlere ilişkin görüşlerinden bazıları aşağıda verilmiştir:

"Birçok öğrenci çok güzel kitap, Türkçe çözmek bu kadar zevkli olmamıştı gibi yorumlar yapıyor. Aynı şekilde kitaplarımızı alan tavsiye eden öğretmenler de sürekli bu konuda öğrencilerin ilgisini çekmeyi

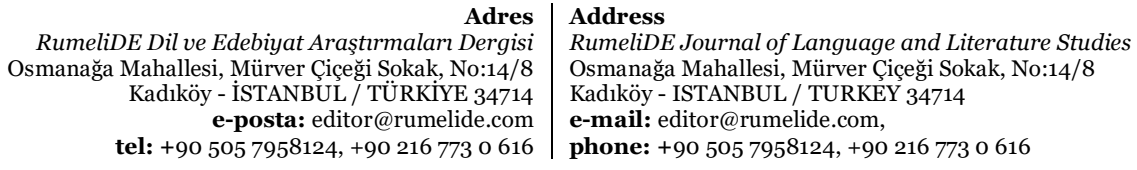


başardığımızı, onları Türkçe çözmeye teşvik ettiğimizi dile getiriyorlar. Kısacası bizim aslında temeli oturttuğumuz şey, yani öğrencinin ilgisini çekmek, onun hoşuna gidecek tarzda sorular yazmayı başardığımızı düşünüyorum.” (Y1).

"Yani öğrencilerimiz kaynak kitaplara onlara birer yardımcı gözüyle bakıyorlar. Olmazsa olmaz olarak bakıyorlar. Ayrıca sadece sinav grubu öğrencilerinin değil alt simıflarda, ara simıflarda okula devam eden, derslerine iyi bir şekilde, başarılı bir şekilde tamamlamak isteyen öğrenciler de kaynak kitaplardan yeterince faydalanıyor. Ara sını öğrencileri kazanımları pekiştirme de konuları kavramada ve tekrar yapma da kaynak kitaplarımdan çoğunlukla faydalanmakta, onlarm da bu konuda kaynak kitaplarn olması gerektiği yönünde görüş bildirdiğini söyleyebilirim.”(Y2).

"Hocalarmızdan kitapların artıları, eksilerine dair dönütler istiyoruz. Şu ana kadar oluşturduğumuz kitaplarla ilgili açıkçası çok olumlu dönüşler aldık. Kendilerinin de sınıflarında bunu kullandıklarmı gördük. Bu anlamda şu an için çok olumsuz bir dönüt almadık ama tabii ki her sene bu kitaplarn güncellenme ihtiyacı olduğu için yeni bir imajla yeni bir kapak veya tasarmla yenilenmiş sorularla güncellenmiş sorularla gönderiyoruz. Bu da çalışmaya olumlu bir izlenim kazandırıyor.” (Y3).

Yazarların olumsuz dönütlere ait görüşlerinden bazıları aşağıda verilmiştir:

"Öğrenciler özellikle sınav grubu çalışan öğrenciler biraz daha renklendirilmiş kitapları tercih ettiğini söylüyorlar.” (Y3).

"Ülkemizde herkesin gelir seviyesi eşit değil, bazı öğretmen arkadaşlar bütün öğrencilerin ulaşamamasından dolayı, eğitim eşitliği adına, tercih etmiyor.” (Y4).

"Biz biraz da öğretmenler olarak hazırcıyız. Böyle çok net hemen üstte bulunan, hiç düşünmeden işaretlenecek şeyleri arıyoruz. Böyle ilk etapta bizim sorularmız da olumlu tepkilerin yanında olumsuz tepkiler de aldr." (Y6).

\section{Yazarların kaynak kitapların öğrenci başarısına katkısına ilişkin görüşleri}

Yazarlar; kaynak kitapların öğrencilerin akademik başarılarına olumlu katkısı, düşünme becerilerini geliştirmesi, sınav sistemine hazırlaması, öğrenilenlerin pekiştirilmesi ve $\mathrm{Z}$ kitaplar nedeniyle kaynaklara kolay ulaşımın olması şeklinde görüşler ifade etmişlerdir. Bu görüşler Şekil 8'de gösterilmiştir.

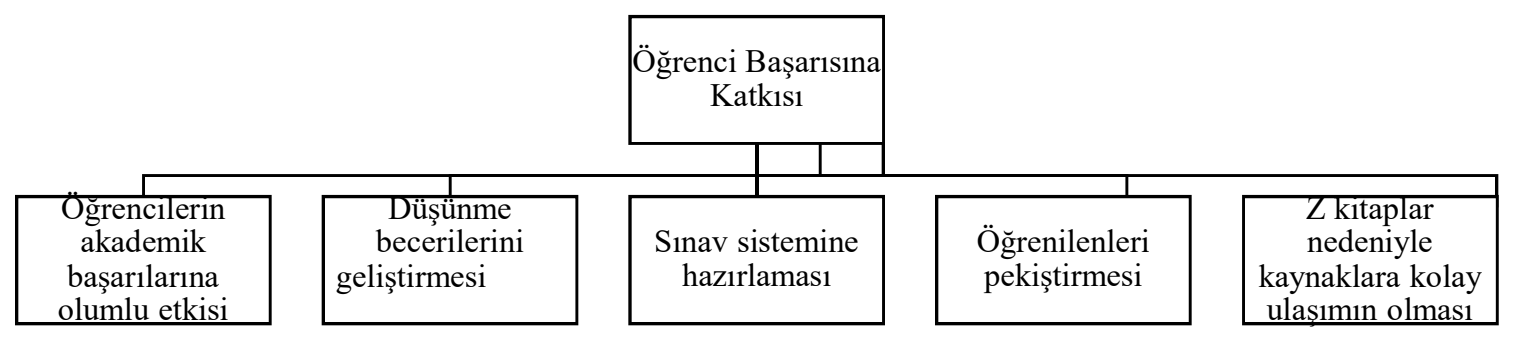

Şekil 8. Kaynak kitapların öğrenci başarısına katkısı

\begin{tabular}{r|l} 
Adres & Address \\
RumeliDE Dil ve Edebiyat Araştırmaları Dergisi & RumeliDE Journal of Language and Literature Studies \\
Osmanağa Mahallesi, Mürver Çiçeği Sokak, No:14/8 & Osmanağa Mahallesi, Mürver Çiçeği Sokak, No:14/8 \\
Kadı̈öy - İSTANBUL / TÜRKIYE 34714 & Kadıöy - ISTANBUL / TURKEY 34714 \\
e-posta: editor@rumelide.com & e-mail: editor@rumelide.com, \\
tel: +90 505 7958124, +90 2167730616 & phone: +90 505 7958124, +90 2167730616
\end{tabular}


Yazarların kaynak kitapların öğrenci başarısına katkısına ait görüşlerden bazıları aşağı̀da verilmiştir:

"Gerçekten de öğrencileri düşündürecek, onların üst düzey düşünme becerilerine katkıda bulunacak, bu becerilerini geliştirecek soruları hazırlamaya çalışıyoruz.” (Y1).

“Türkçe öğretmeni olarak bunu ben de söyleyebilirim. Sadece MEB'in dağıtmış olduğu MEB tarafindan verilen kitaplarla Türkçe dersinde başar mümkün mü? Çok mümkün değil. Yani yayınlanan örnek sorulara, LGS'de çıkmış sorulara baktığını zaman kitaptaki sorularla sinav sorularının çok fazla örtüşmediğini görüyoruz. Bu da dolayısıyla öğrencileri, velileri, öğretmenleri yardımcı kaynak kitapları kullanmaya itiyor. Yardımcı kaynak kitaplar da öğrencilerin başarılarına mutlaka çok büyük etki ediyor, diyebilirim.” (Y2).

“Test çözmeye odakl bir öğrenci profili olduğu için 5’inci sinıftan itibaren bu kaynak kitapları alıyorlar ve soru çözme, test çözme becerisini geliştiriyorlar. 8. sinıfa gelen öğrencilerde bunu yapanlarm çok daha avantajl olduğunu görebiliyoruz. Özellikle sinava yönelik bir antrenman kazanıyorlar süre içerisinde, bu da çocuklarm performansını olumlu yönde etkiliyor.”(Y3).

"Kaynak kitabı doğru seçen öğrenci okulda gördüğ̈̈ konuları evde pekiştirerek, bol bol soru çözerek tam bir öğrenme sağlanmış oluyor. Bu nedenle kaynak kitapların öğrenci başarısına doğrudan bir etkisi olduğunu düşünüyorum.” (Y4).

\section{Yazarların eklemek istedikleri görüşler}

Yapılan görüşme neticesinde yazarlara eklemek istedikleriniz var mı, sorusuna yazarlar; kaynakların kontrolsüz çoğalmasının niteliği etkilemesi, maddi kaygıların işin önüne geçmesi, kaynak kitap yazmak için gerekli yazar niteliklerinin göz ardı edilmesi, MEB’in bu konuda denetlemesinin gerekliliği, yayınevleri için belirli standartların getirilmesi ve sınav sistemi var oldukça kaynak kitaplara her zaman ihtiyaç olacağı şeklinde görüşlerini belirtmişlerdir. Bu görüşler Şekil 9'da gösterilmiştir.

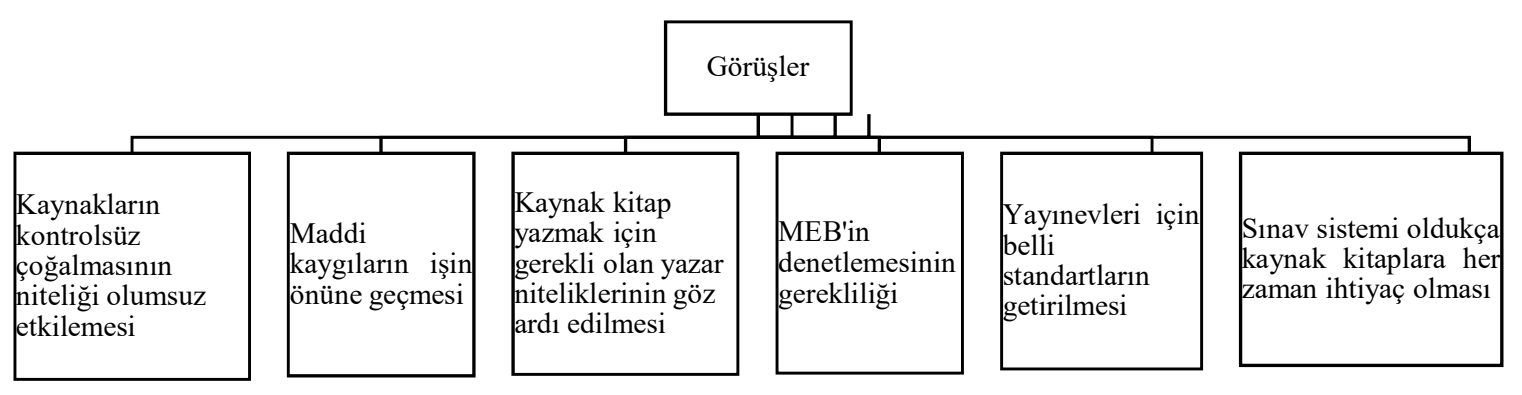

Şekil 9. Yazarların eklemek istedikleri görüşler

Kaynak kitap yazmanın herhangi bir denetime tabi olmaması, hazırlanan kaynak kitapların içeriğinin sadece yayınevinin kontrolünden geçmesi, kaynak kitapları nitelik ve nicelik açısından etkilediği yazarlar tarafından ifade edilmiştir. Ayrıca kazanımları ölçmeye, verilen kazanımların pekiştirilmesine yardımcı olmaya yönelik hazırlanan kaynak kitapların resmi bir kurum tarafından denetlenmesi ve bu denetimler sonucunda bu kitapların piyasaya sürülmesi hem öğrencilerin nitelikli eserlerle

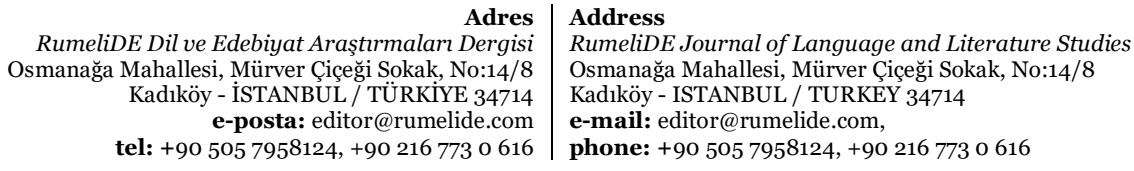


karşılaşmasında hem de yazarların nitelikli hale gelmesinde etkili olabileceği konusunda yazarlar görüş bildirmiştir. Talim Terbiye Kurulu Başkanlığı gibi bir mekanizmanın kaynak kitapları şekil ve içerik bakımından incelemesi, bunun neticesinde bir uygunluk belgesi vermesi piyasaya nitelik ve nicelik açısından doyurucu kaynak kitapların çıkmasını sağlayacağı belirtilmiştir.

Bazı yayınevlerinin her kazanımdan ve konudan soru olsun mantığına sahip olması da kaynak kitapların niteliğini olumsuz yönde etkilediği yazarlar tarafından ifade edilmiştir. Maddi çıkarın gözetilmesi; soru yazma tekniklerinin göz ardı edilmesine, bu işin eğitimini almamış kişilerin de kaynak kitap yazma girişiminde bulunmasına ve bunun neticesinde piyasada kaynak kitap adı altında kazanımlarla ilgisi olmayan, hiçbir kazanımı ölçmeyen, anlaşılmaz zor sorular nedeniyle öğrencilerde Türkçe dersine karşı olumsuz tutum oluşturan kitapların ortaya çıkacağı belirtilmiştir.

"Eklemek istedikleriniz nelerdir?” sorusuna kaynak kitap yazarları tarafından sınav sistemi oldukça kaynak kitapların öğretmenler, öğrenciler ve veliler açısından vazgeçilmez bir materyal olmaya devam edeceği görüşü belirtilmiştir. Kaynak kitap yazarlarının görüşlerinden bazıları aşağıya verilmiştir:

"Son yıllarda maalesef sinavlardan da kaynaklanan yayın sektörünün öncü bir ihtiyaç haline gelmesi birçok kişinin bu sektöre girmesine sebep oldu. Haliyle tabi sektörde çeşitlilik arttı, ayn zamanda kirlilik de arttı. Yani bu işüzerine kafa yormayan bu işe sadece ticaret gözüyle bakan insanlar türedi. Bu maalesef bizim çahş̧malarmmza ciddi anlamda zarar veriyor.” (Y1).

"Kaynak kitap yazma çok ciddi ve meşakkatli bir iş. Belki bir kontrol mekanizması belki bir standart özellikle yaymevlerine getirilecek bir standart bunu çok daha olumlu yönde etkileyecektir.” (Y3).

“Sinavlar olduğu müddetçe yardımcı kaynaklara ihtiyaç hep olacaktır.” (Y4).

\section{Sonuç, tartışma ve öneriler}

Araştırmanın neticesinde Türkçe dersine yönelik kaynak kitap hazırlayan yazarların görüşleri tema haline getirilerek "İçerik, gerekçe, kaynak kitap hazırlarken karşlaşılan zorluklar, karşılaşılan zorlukların çözüm yolları, kaynak kitapların Türkçe öğretimine katkısı, kaynak kitaplara ilişkin alınan dönütler, kaynak kitapların öğrenci başarısına katkısı, diğer görüşler” başlıkları altında değerlendirilmiştir.

Kaynak kitap yazarlarının öğrencilerin ihtiyaçları doğrultusunda farklı içeriklere sahip ürünler ortaya koydukları yapılan değerlendirmeler neticesinde anlaşılmıştır. Ortaya konan ürünlerin çeşitlilik göstermesinde MEB sınavlarının zamanla değişen içeriğinin ve öğretim programındaki güncellemelerin etkisi olduğu düşünülebilir. Ders kitapları dışında farklı içeriklere sahip kaynak kitap ihtiyacı MEB tarafından da yapılan saha çalışmalarıyla ortaya konmuş ve öğrencilerin ihtiyaçlarını ve farklılaştırılmış öğretimi dikkate almak, çocuklara bireysel gelişimlerine göre kaynaklar sunabilmek ve öğretmenlere destek olmak için farklı nitelikte kaynak kitaplar öğretmen, öğrenci ve veli görüşleri doğrultusunda hazırlanarak okullara dağıtılmıştır (“Kitabım hep açık; okulda, evde, öğretmenimle, ailemle”, 2020).

Alan yazın taraması yapıldığında kaynak kitap yazarlarının görüşlerini içeren herhangi bir çalışmaya rastlanılmamıştır. Ancak bu çalışmanın temalarından birisi olan 'Kaynak Kitap Hazırlama Gerekçeleri' ile ilgili olabilecek çeşitli çalışmalara alan yazın taramasında rastlanılmıştır. Yılmaz (2020), Haşıloğlu, Güler ve Durmaz (2020), Taş ve Minaz (2018), Katipoğlu ve Katipoğlu (2016), Güngör ve Çavuş (2015), Mazlum ve Mazlum (2016) yaptıkları çalışmalarda ders kitaplarının öğrencileri sınavlara hazırlama

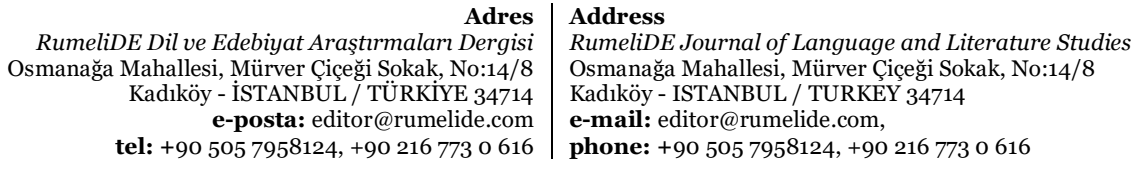


noktasında eksik kaldığı, yardımcı kitapların içerik açısından ders kitaplarından daha zengin olduğu, MEB sınavlarına benzer soruların yardımcı kitaplarda var olduğu, bu kitaplarda etkinlik ve soru sayısının fazla olduğu, yardımcı kitapların ders kitaplarının sıkıcılığını ortadan kaldırdığı, öğrencilerin ders başarılarında yardımcı kaynakların daha etkili olduğu gibi sonuçlara ulaşmışlardır. Kaynak kitap hazırlayan yazarların gerekçeleri ile bahsedilen çalışmaların sonuçları birbirleri ile paralellik göstermektedir. Zira kaynak kitap yazarları aktif olarak MEB'de görev yaptıkları için ders kitaplarının eksik yönlerini gidermek ve öğrencilerin kazanımlarını pekiştirmek maksadı ile kaynak kitap hazırladıklarını belirtmişlerdir.

Kaynak kitap yazarları kitaplarını oluştururken çeşitli zorluklarla karşılaştıklarını belirtmişlerdir. Bu zorluklar "kazanımların net olmaması, kazanımlarını sınıf seviyesine göre ayrılmaması/kazanımların çoğunun her sınıfta aynı olması, zaman sorununun olması, yayınevlerinin öğretim programının içeriğinin dışında soru istemesi, öğretim programının sık değişmesi, TDK'nin yazım kurallarının tutarsız olması, görsel ve grafik sorularında dizgi sorununun yaşanması ve telif sorunun olması" başlıklarında toplanmıştır. Ancak bu zorluklardan MEB’i doğrudan ilgilendiren "kazanımların net olmaması, kazanımların sınıf seviyesine göre ayrılmaması/kazanımların çoğunun her sınıfta aynı olması ve öğretim programının sık değişmesi”dir. Bu zorluklar yazarların kendileri ile ilgili olmadığı için yazarlar bu zorlukları var olan duruma uygun sorular yazarak aşmak zorunda kalmışlardır.

Kaynak kitapların Türkçe öğretimine "öğretmenlere rehberlik etmesi, kazanımların kavranmasında ve pekiştirilmesinde katkı sağlaması, seviyeye göre hazırlanmış kaynakların öğrencileri derse karşı motive etmesi, mesleğin içinde olan yazarların sorunları daha doğru tespit etmesi ve çözüm yolları bulması, konuların öğretilmesinin kolaylaştırılması, öğrencilerin üst düzey düşünme becerilerine katkı sağlaması" gibi başlıklarda katkı sağladığına ilişkin yazarlar görüşlerini ifade etmiştir.. Ayrıca Kaynak kitapların öğrencilerin akademik başarılarına etki etmesi, düşünme becerilerini geliştirmesi, sınav sistemine hazırlaması, öğrenilenlerin pekiştirilmesi açısından etkili olduğuna yönelik görüşler ifade edilmiştir. Güngör ve Çavuş (2015) tarafından yürütülen deneysel çalışmada yardımcı kitap kullanılarak ders işlenen deney grubu ile sadece ders kitabı kullanılarak ders işlenen kontrol grubunun kesirler konusunda akademik başarısı ve kalıcılı̆̆ karşılaştırılmıştır. Sonuçlar her iki değişkende de deney grubu lehine çıkmıştır. Araştırmada yardımcı kaynakların etkinlik bakımından zengin olmasının, öğrencilerin başarılarını olumlu etkilediği sonucuna ulaşılmıştır. Benzer şekilde Taş ve Minaz (2018) öğretmen, öğrenci ve velilerle kaynak kitaplar hakkında görüşme yapmıştır. Araştırma sonucunda katılımcıların tamamının kaynak kitapları ihtiyaç olarak gördüğü, kaynak kitapların ders kitabına göre daha eğlenceli, kaliteli ve ilgi çekici bulunduğu, kaynak kitapların öğrencilerde gelişimi desteklediği görüşünde oldukları sonucuna ulaşmıştır. Kaynak kitaplara neden ihtiyaç duyulduğu sorusunu cevabı diğer bir açıdan bu kitapların sağladığı katkılarla doğru orantılıdır. Öğretmenler ve öğrenciler ders kitaplarında gördükleri eksiklikler nedeniyle yöneldikleri kaynak kitaplardan olumlu yönde fayda elde ettiklerini ifade etmektedir.

Oluşturulan kaynak kitaplar hakkında kitapların yazarlarına olumlu veya olumsuz olarak geri dönütler verilmiştir. Kaynak kitaplara ilişkin hem olumlu hem de olumsuz dönütler verilmesi kaynak kitapların eksiklerinin giderilmesi, kaynak kitaptan faydalanan öğretmen ve öğrencilerin daha doğru bilgiler içeren kaynaklara ulaşması adına önemlidir.

Kaynak kitap yazarları görüşmenin sonunda sorulan eklemek istedikleriniz var $\mathrm{ml}$, sorusuna "kaynakların kontrolsüz çoğalmasının niteliği etkilemesi, maddi kaygıların işin önüne geçmesi, kaynak kitap yazmak için gerekli yazar niteliklerinin göz ardı edilmesi, MEB'in bu konuda denetlemesinin

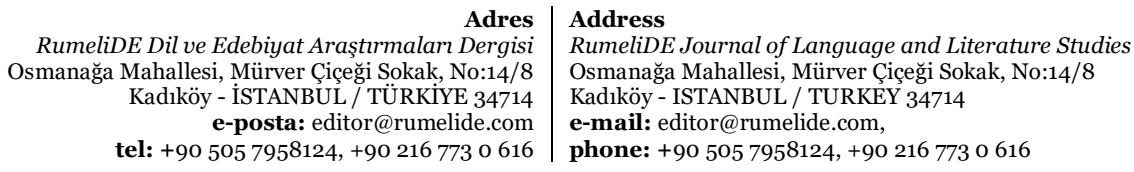


gerekliliği, yayınevleri için belirli standartların getirilmesi ve sınav sistemi var oldukça kaynak kitaplara her zaman ihtiyaç olacağı” şeklinde görüşler bildirmişlerdir. Türk Yayıncılar Birliğinin 2020 yllına ait hazırladığı kitap pazarı raporuna göre basılan kitaplar arasında en büyük pay \%52,80’lik bir oranla eğitim kitaplarına aittir (TÜRKYAYBİR, 2020). Türk İstatistik Kurumu verilerine göre eğitim harcamaları her geçen yıl artmaktadır (TÜİK, 2020). Ders kitapları bakanlık tarafından ücretsiz dağıtıldığından eğitim kitapları arasında en büyük pazarı yardımcı kitaplar oluşturmaktadır. Büyük ve dinamik bir pazar olan kaynak kitapların hazırlanmasına ve basımına yönelik nitelik sorunlarını olabilmektedir. Bu görüşlerden anlaşılacağı üzere kaynak kitapların oluşturulma sürecinde resmi bir kurumun denetiminin olmaması, kaynak kitapların şekil ve içerik yönünden denetimsiz bir şekilde piyasaya sürülmesine neden olmaktadır. Kaynak kitap oluşturacak kişilerin kendilerini ölçme ve değerlendirme konusunda geliştirmek amacıyla açılan hizmet içi eğitimlere katılmaları nitelikli eserler oluşturmalarına yardımcı olacaktır.

Araştırmadan elde edilen sonuçlar ışığında şu önerilerde bulunulabilir:

- Ders kitaplarının geliştirilmesinde var olan sınav sistemi de dikkate alınarak farklı nitelikte ders kitapları hazırlanabilir.

- Ders kitapları oluşturulurken dönemin gereksinimleri, öğretmen ve öğrencilerin ihtiyaçları dikkate alınabilir.

- Yardımcı kitapların denetimi ve yayınevlerinin kontrolü için gereken denetim mekanizması oluşturulabilir.

- Kaynak kitap konusunda yasal düzenlemeler yapılarak kullanımında esneklik sağlanabilir.

- Bu araştırmanın sonuçları göz önüne alınarak eğitim öğretim sürecindeki farklı paydaşların kaynak kitaplarla ilgili görüşlerini temel alan farklı araştırmalar yapılabilir.

- Yardımcı kitap kullanımına yönelik sınıf ortamında farklı veri toplama araçlarıyla derinlemesine araştırmalar yapılabilir.

\section{Kaynakça}

Altun, M., Arslan, Ç. ve Yazgan, Y. (2004). Lise matematik ders kitaplarının kullanım şekli ve sıklı̆̆ üzerine bir çalışma. Uludağ Üniversitesi Eğitim Fakültesi Dergisi, 17(2), 131-147.

Binbaşığlu, C. (1973). Öğretim metodu ve uygulama. Ankara, Binbaşığlu.

Bloor, M. and Wood, F. (2006) Keywords in Qualitative Methods. London: Sage Publications. https://dx.doi.org/10.4135/9781849209403

Büyüköztürk, Ş., Çakmak, E. K., Akgün, Ö.E., Karadeniz, Ş. ve Demirel, F. (2016). Bilimsel araşttrma yöntemleri. Ankara: Pegem Akademi.

Chirstensen, L. B., Johnson, R. B. \& Turner, L. A. (2015). Araştırma yöntemleri desen ve analiz (Çev. Ed. A. Aypay). Ankara: Anı.

Creswell, J. W. (2013). Nitel araştırma yöntemleri (Beş yaklaşıma göre nitel araştırma ve araştırma deseni (Çev. Ed. M. Bütün ve S. B. Demir). Ankara: Siyasal.

Çağ, H. D. (2020). 5. sınıf Türkçe ders kitabının öğretmen görüşleri doğrultusunda değerlendirilmesi. International Journal of Language Academy 34(34), 82-98 DOI:10.29228/ijla.40209.

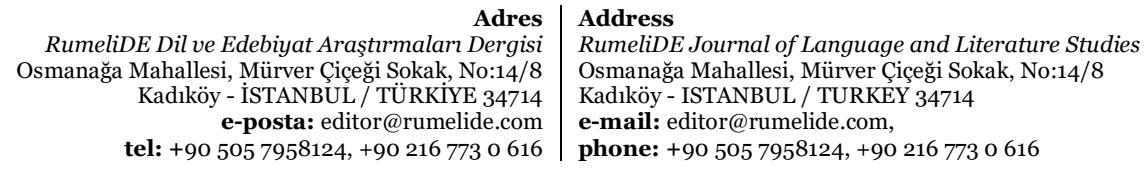


Çalık, T. (2001). Türkçe ders kitaplarının biçim ve tasarımı. İçinde L. Küçükahmet (Ed.) Konu alanı ders kitabı inceleme kılavuzu (1-14).Ankara:Nobel.

Demirel, Ö. ve Kıroğlu, K. (2005). Konu alanı ders kitabı incelemesi. Ankara: Pegem A.

Eddles-Hirsch, K. (2015). Phenomenology and educational research. International Journal of Advanced Research, 3(8), 251-260.

Güngör, H. ve Çavuş, H. (2015). İlkokul 4. sınıf matematik dersi "kesirler" konusunun öğretiminde öğretmenin yardımcı kitap kullanımının öğrenci başarısı üzerindeki etkisi. Ahi Evran Üniversitesi Kırşehir Eğitim Fakültesi Dergisi, 16 (2), 251-271.

Gürbüz, S. ve Şahin, F. (2016). Sosyal bilimlerde araştırma yöntemleri felsefe-yöntem-analiz. Ankara: Seçkin.

Haşıloğlu, M., A., Güler, H. ve Durmaz, E. (2020). Ortaokul sosyal bilgiler ve fen bilimleri öğretmenlerinin yardımcı kitap kullanma nedenleri ile ilgili görüşleri. EKEV Akademi Dergisi, 83. Erişim adresi: http://dx.doi.org/10.17753/Ekev1520

Karakoç, B. (2019). Olgubilim Araştırması. S. Şen ve İ. Yıldırım (Ed.), Eğitimde Araştırma Yöntemleri İçinde (s. 263-280). Ankara: Nobel Yayınları.

Katipoğlu, M. ve Katipoğlu, S. N. (2016). Matematik öğretmenlerinin öğrenci ders kitabı hakkındaki görüşleri. Uluslararası Eğitim Bilim ve Teknoloji Dergisi, 2(3), 156-165.

Kitabım hep açık; okulda, evde, öğretmenimle, ailemle. (2020, Kasım). Erişim adresi: http://www.meb.gov.tr/kitabim-hep-acik-okulda-evde-ogretmenimle-ailemle/haber/21979/tr

Kvale, S. 1996. Interviews: An Introduction to Qualitative Research Interviewing, London: Sage.

Mazlum, Ö. ve Mazlum, S. F. (2016). İlköğretim 4. sınıf ders kitaplarının görsel tasarımına yönelik öğretmen görüşlerinin değerlendirilmesi. Sanat Ĕ̆itimi Dergisi, 4(1), 1-18.

MEB (2016). Milli Eğitim Bakanlığı Ders Kitapları ve Eğitim Araçları Yönetmeliği. Ankara: MEB Yayınları. Erişim adresi: http://mevzuat.meb.gov.tr/dosyalar/1605.pdf

MEB (2018). MEB Ortaöğretim Genel Müdürlüğü’nün 25.09.2018 tarih ve 21658195-115.01- E. 17412997 sayılı yazısı

Miles, M. B. ve Huberman, A. M. (2016). Nitel veri analizi. (Çeviri Ed. Akbaba Altun S. ve Ersoy, A.). Ankara: Ankara Pegem A Akademi. (2. Baskı).

Öztürk, A. T. (2019). Türkçe öğretmenlerinin ders kitaplarına bağlllık durumları (Yüksek Lisans Tezi). Gaziantep Üniversitesi Ĕ̆itim Bilimleri Enstitüsü, Gaziantep.

Patton, M.Q. (2014). Nitel araştırma ve değerlendirme yöntemleri. (3. Baskıdan Çeviri ed. Bütün, M \& Demir, S. B. ), Ankara: Pegem Akademi.

Saldana, J. (2011). Fundamentals of Qualitative Research. Oxford University Press, İngiltere.

Taş, H. ve Minaz, M. B. (2018). Derslerde yardımcı kaynak kullanılmasının öğretmen, veli ve öğrenci görüşlerine göre değerlendirilmesi. SETSCI Conference Indexing System, 3(4), 582-589.

TEDMEM. (2015). Okul özerkliği ve öğretmen özerkliği. Erişim adresi: https://tedmem.org/memnotlari/degerlendirme/ogretmen-ozerkligi-ve-okul-ozerkligi-uzerine.

TÜİK(2020). Eğitim Harcamaları İstatistikleri, 2019. Erişim adresi: https://data.tuik.gov.tr/Bulten/Index?p=Egitim-Harcamalari-Istatistikleri-2019-33670

TÜRKYAYBİR (2019). Türkiye kitap pazarı raporları. Erişim adresi: http://turkyaybir.org.tr/2019yilinin-11-aylik-toplam-kitap-uretim-verileri/\#.YBHooOgzaUk

TÜRKYAYBİR (2020). 2020 yılı Türkiye kitap pazarı raporları. Erişim Adresi: https://turkyaybir.org.tr/wp-content/uploads/2021/04/Kitap-Pazari-Raporu_2020.pdf

Ünsal, Y. ve Güneş, B. (2004): Bir kitap inceleme çalışması örneği olarak MEB lise 1. sınıf fizik ders kitabının eleştirel olarak incelenmesi, Gazi Üniversitesi Türk Eğitim Bilimleri Dergisi, 2 (3), 305321

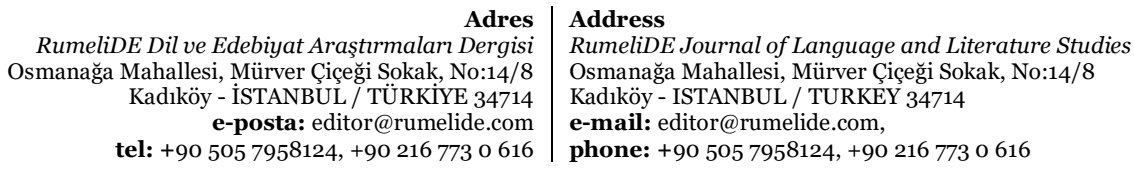


54 / RumeliDE Journal of Language and Literature Studies 2021.24 (September)

I am writing a sourcebook for teaching Turkish ...: A phenomenological study / B. Özdemir; Y. Aydoğan (pp. 34-54)

Yıldırım, A. ve Şimşek, H. (2016). Sosyal bilimlerde nitel araştırma yöntemleri. Ankara: Seçkin.

Yılmaz, M. (2020). Yardımcı ders kitabı kullanımına ilişkin sınıf öğretmenlerinin görüşlerinin değerlendirilmesi. International Social Mentality and Researcher Thinkers Journal, 6(32), 804811.

Adres | Address

RumeliDE Dil ve Edebiyat Araştırmaları Dergisi Osmanağa Mahallesi, Mürver Çiçeği Sokak, No:14/8 Kadıköy - İSTANBUL / TÜRKIYE 34714 e-posta: editor@rumelide.com

RumeliDE Journal of Language and Literature Studies Osmanağa Mahallesi, Mürver Çiçeği Sokak, No:14/8

Kadıköy - ISTANBUL / TURKEY 34714

e-mail: editor@rumelide.com

tel: +90 505 7958124, +90 2167730616 phone: +90 505 7958124, +90 2167730616 